\title{
Selection of the Proper Diffusion Welding Parameters for the Heterogeneous Joint Ti Grade 2/AISI 316L
}

\author{
Jaromir Moravec $^{1}$, Martina Dikovits ${ }^{2}$, Coline Beal ${ }^{2}$, Iva Novakova ${ }^{1}$, Rebecca Chandezon ${ }^{2}$, Jiri Sobotka ${ }^{1}$ \\ ${ }^{1}$ Technical University of Liberec. Studentská 2, 46117 Liberec 1. Czech Republic. E-mail: jaromir.moravec@tul.cz, \\ iva.novakova@tul.cz,jiri.sobotka@tul.cz \\ ${ }^{2}$ Graz University of Technology, Kopernikusgasse 24/I, 8010 Graz, Austria. E-mail: martina.dikovits@tugraz.at, co- \\ line.beal@tugraz.at, rebecca.chandezon@insa-lyon.fr
}

The creation of the heterogeneous joints at materials with the different physical and mechanical properties is always problematic. As one of methods by which can be achieved very good results is there a diffusion welding. The aim of paper is to show the possibilities of diffusion welding utilization at creation the heterogeneous joints between Titan grade 2 and high-alloyed austenitic steel AISI 316L. The fundamental theory of diffusion and also scheme and realization of experimentally created diffusion welds in the thermal-mechanical simulator Gleeble ${ }^{\circledR} 3500$ is described in the article. Furthermore, procedure of technological parameters selection when optimization of heterogeneous joint strength properties including metallographic evaluation are taken into account, are also presented.

Keywords: diffusion welding, Gleeble ${ }^{\circledR} 3500$ and 3800, 316L steel, Ti Grade 2, processing parameters

\section{Acknowledgement}

This paper was prepared thanks to support from the Aktion project No. 73 p7.

\section{References}

[1] PLUHAŘ, J., A. PUSKAR, J. KOUTSKÝ, J. MACEK and V. BENEŠ (1987). Fyzikální metalurgie a mezní stavy materiálu, SNTL/ALFA, Praha.

[2] SYMONOVA, A., F. DUCOBU and V. WEISS (2016). The Mechanics of Machining Ultrafine-Grained Grade 2 Ti Processed Severe Plastic Deformation. In: Manufacturing Technology, Vol. 16, No. 3, pp. 627-633.

[3] VOLENIK, O. (1964). Difuze v kovech. In: ČS časopis pro fyziku.

[4] BAČA, A., R. KONEČNÁ, G. NICOLETTO and L. KUNZ (2015). Effect of Surface Roughness on the Fatigue Life of Laser Additive Manufactured Ti6Al4V Alloy, In: Manufacturing Technology, Vol. 15, No. 4, pp. 498-502.

[5] S. KUNDU, S. CHATTERJEE (2006). Interfacial microstructure and mechanical properties of diffusion-bonded titanium-stainless steel joints using a nickel interlayer. In: Materials Science and Engineering A, Vol. 425, pp. $107-113$.

[6] S. KUNDU, S. CHATTERJEE (2008). Characterization of diffusion bonded joint between titanium and 304 stainless steel using a Ni interlayer. In: Materials Characterization, Vol. 59, pp. 631-637.

[7] S. KUNDU, M. GHOSH, A. LAIK, K. BHANUMURTHY, G.B. KALE and S. CHATTERJEE (2005). Diffusion bonding of commercially pure titanium to 304 stainless steel using copper interlayer. In: Materials Science and Engineering A, Vol. 407, pp. 154-160.

[8] DOPJERA, D., R. KOŇÁR and M. MIČIAN (2014). Ultrasonic Testing of Girth Welded Joint with TOFD and Phased Array. In: Manufacturing Technology, Vol. 14, No. 3, pp. 281-286.

[9] KOLAŘíK, L., M. KOLǍ̌ÍKOVÁ, P. NOVÁK, M. SAHUL and P. VONDROUŠ (2013). The Influence of Nickel Interlayer for Diffusion Welding of Titanium and Austenitic Steel. In: 22nd International Conference on Metallurgy and Materials METAL 2013. Ostrava: TANGER Ltd., s. 508-513.

[10] KOLAŘÍK, L., M. KOLAŘÍKOVÁ and P. VONDROUŠ (2014). Mechanical Properties of Interface of Heterogeneous Diffusion Welds of Titanium and Austenitic Steel. In: Key Engineering Materials, Vol. 586, pp. 178-181.

ARUN, S., N. HARIKRISHNA, A. J. JAHANGIR, A. JEGANATHPRABHU, W. EDWIN LYONAL a G. MAHANDEVAN (2015). Optimization of Process Parameters of Diffusion Bonding in Titanium with Stainless Steel. In: International Journal of Engineering and Technology [online]. Vol. 4, No. 1, ISSN 2319-5991. Dostupné z: http://www.ijerst.com/ijerstadmin/upload/IJEETC_55235855a70b6.pdf\#page=5\&zoom= auto,-178,460.

[11] ALEMAN, B., L. GUTIERREZ and J. URCOLA (1993). Interface microstructures in diffusion bonding of titanium alloys to stainless and low-alloy steels. In: Materials Science and Technology, Vol. 9, pp. 633-641. 
[12] M. GHOSH, K. BHANUMURTHY, G.B. KALE, J. KRISHNAN, S. CHATTERJEE (2003). Diffusion bonding of titanium to 304 stainless steel. In: Journal of Nuclear Materials, Vol. 322, pp. 235-241.

[13] M. GHOSH, S. CHATTERJEE (2005). Effect of interface microstructure on the bond strength of the diffusion welded joints between titanium and stainless steel. In: Materials Characterization, Vol. 54, pp. 327- 337.

[14] M. GHOSH, S. DAS, P.S. BANARJEE, S. CHATTERJEE (2005). Variation in the reaction zone and its effects on the strength of diffusion bonded titanium-stainless steel couple. In: Materials Science and Engineering A, Vol. 390, pp. 217-226.

\section{Paper number: M201742}

Copyright (C) 2017. Published by Manufacturing Technology. All rights reserved. 